\title{
粉砕された酸化亜鉛の格子ひず夕について*
}

\author{
岩 崎 弘 通** 松 田二 郎***
}

\section{The Lattice Distortion of Ballmilled Zinc Oxide}

by

Hiromichi IwASAKI and Jiro MATSUdA

(Faculty of Science and Engineering, Ritsumeikan University, Kyoto)

There have been hitherto many studies on the crystallite size and the lattice distortion of the ground zinc oxide powder by X-ray diffraction method. However, it seems that the thermal analysis is as effective for the study on the lattice distortion of the ground powder as the X-ray diffraction method.

For this reason, the zinc oxide ground by a ball mill was studied by the thermal analysis, and the results were compared with the results obtained by the X-ray diffraction method. Moreover, the effects of heat-treatment of the ground zinc oxide on the disappearance of lattice distortion and on the growth of crystallite were also studied. As a result, an exothermal peak was found between $220^{\circ}$ and $260^{\circ} \mathrm{C}$ in the heating process of the differential thermal analysis, but no change of the weight could be found at those temperatures. As the grinding time became longer, this exothermal peak shifted to a higher temperature and became larger. This exothermal peak in the heating process may be attributed to the discharge of lattice distortion energy.

The lattice distortion increased with grinding time up to 200 hours, but after 200 hours it increased little. Such lattice distortion diminished or disappeared easily by heating at $200^{\circ} \mathrm{C}$, and gradually diminished even at room temperature after a long time.

On the other hand, the crystallite size increased gradually by heating above $200^{\circ} \mathrm{C}$ and rapidly above $700^{\circ} \mathrm{C}$.

(Received Nov. 10, 1972)

\section{1 緒言}

粉碎，加圧などの機械的エネルギを固体物質に加兄 た場合，それらの固体物質が，結晶質，あるいは非結 晶質のいかんにかかわらず, それら物質の物理化学的 性質の変化，たと壳ば粒度変化，格子ひずみ，欠陷の 発生, 結晶質の無定形化, 非結晶質の結晶化などを生 じ, あるいは吸着, 反応性, 溶解熱などの諸現象にも 変化を生じる。

これらのいわゆるメカノケミカルな効果を生じる主 要な原因としては, 新鮮面の生成以外飞欠陥, 格子ひ ずみなどの格子不整が考兄られ，乙たがって不定比化 合物を作りやすい遷移金属酸化物ではとくにメカノケ ミカルな効果が大さいことが予測され，事実これら酸 化物に対するこの方面の研究例は多い。

* 原稿受理 昭和 47 年 11 月 10 日

** 正 会 員 立命館大学理工学部 京都市北区等持院北町

*** 立命館大学理工学部 京都市北区等持院北町
酸化亜鉛の結晶構造に及ぼす粉碎効果についても従 来まで多くの研究例があるが，それらはX線回折によ る格子ひずみ，あるいは粒度の測定を中心としたもの が多い，一方欠陷や格子ひず友の生成に伴う副次的効 果がX線回折法以外飞, 反応性, 熱的性質, 吸着能の 変化などによって研究されている。

著者らも先に酸化亜鉛の加熱, 粉碎, 加圧処理など に上る格子不整の生成と吸着構造の変化との関連性を 調べ, 粉砕, あるいは加圧処理之酸化㑹鉛の表面に生 成する欠陥構造との相関性について検討した。

他方粉碎で生じる格子ひずみ発生の状態の研究につ いても従来から多く使われているX線回折法以外飞ひ ずみエネルギの放出に伴う熱的性質の变化の測定が有 効であると考觉られるが，このような観点からの研究 例はきわめて少ない，以上の上らな理由から本研究で は酸化亜鉛の粉碎後の格子ひず可発生，抢上び格子 ひずみに及ぼす加熱効果などを示差熱分析，熱てんび 
ん，溶解熱測定などを用いて調べ，X線回折法による 結果との相関性について検討した.

\section{2 実 験 方 法}

\section{$2 \cdot 1$ 試料}

酸化亜鉛は他の遷移金属酸化物と同様にその構造, 物性などは試料の生成歴, 前処理などにより重要な影 響をらけることが予測される。

本実験の目的は一定の試料について粉砕時間に伴ら 相対的な格子ひずみの増加の状態についてX線回折法 と熱的測定法との結果を比較することにあり，したが って試料としては一定の酸化亜鉛（関東化学製特級試 薬）をあらかじめ $110^{\circ} \mathrm{C}, 10$ 時間空気中で加熱処理し たものを用いた。

上述のように一定の前処理をした試料 $30 \mathrm{~g}$ を日本化 学陶業製ボールミル SSA-A型 (内径 $75 \mathrm{~mm}$, 内容積 $400 \mathrm{ml}$ ) 中で, 室温, 空気中で 40 r.p.m の一定回転 数で 50 ～ 400 時間粉砕した.

格子ひずみ除去のため粉砕後の試料を空気中で 200 $\sim 700^{\circ} \mathrm{C}$ を，各 $100^{\circ} \mathrm{C}$ 間隔でそれぞれ 3 時間加熱処理 を行なった。

\section{$2 \cdot 2$ 測定法}

示差熱分析は島津製 DTA-20 B (Pt七ル，Pt-Pt. $\mathrm{Rh}$ 熱電対）を使用し，標準物質として $\alpha \mathrm{Al}_{2} \mathrm{O}_{3}$ を用 い, 昇温速度 $20^{\circ} \mathrm{C} / \mathrm{min}$ で試料 $50 \mathrm{mg}$ について空気 中で測定した。

熱てんびんは島津製 TGA-20 B により 示差熱分析 と同一条件で測定した。

溶解熱は $30^{\circ} \mathrm{C}\left( \pm 1 / 200^{\circ} \mathrm{C}\right)$ の恒温槽中でガラス製カ ロリメータを用い, 試料 $0.15 \mathrm{~g}$ を $2 \mathrm{~N}$ の塩酸 $100 \mathrm{ml}$ 中に溶解する条件で測定した。

\section{3 結果と考察}

\section{$3 \cdot 1 \mathrm{X}$ 線回折法による粒度と格子ひずみの測定}

従来の他の研究例と比較するために粉砕時間による X線回折の変化, 抢よび Hall 法により求めた, 格子 ひずみ, 粒度の変化を Fig. 1 拈よび Fig. 2 亿示す.

粉碎条件の相違から他の研究例と若南の差はあるが 変化の傾向はほぼ同様である。すなわち50時間粉砕に より粒度は急激に減少するがその後の変化は小さい。 この傾向は電子顕微鏡観察の結果とも一致した. 一方 格子ひずみは粉砕時間とともに徐々に壇大し 300 時間 粉砕でほぼ飽和に達する。さらに粉砕後の試料の加熱 処理による粒度の成長と格子ひずみの除去の状態を調 ベるために一例として 200 時間粉砕試料について加熱 後の測定結果をFig. 3 に示す. 粒度の成長に対する加 熱効果は $700^{\circ} \mathrm{C}$ までは小さいが， $700^{\circ} \mathrm{C}$ 以上では急激 に増大する. 一方格子ひずみに刘する加熱効果は大さ く，200 C の低温処理でほぼ完全に格子ひずみの消失 が認められる。

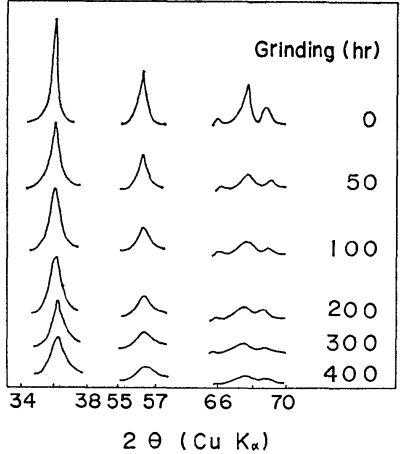

Fig. 1. X-ray diffraction patterns of zinc oxide after grinding.

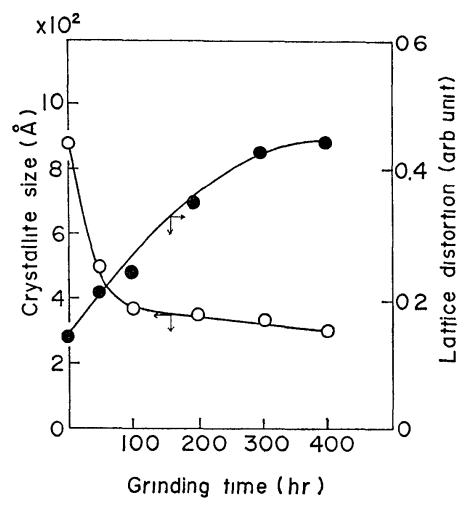

Fig. 2. Change of the crystallite dimension and the lattice distortion of zinc oxide as a function of the grinding time.

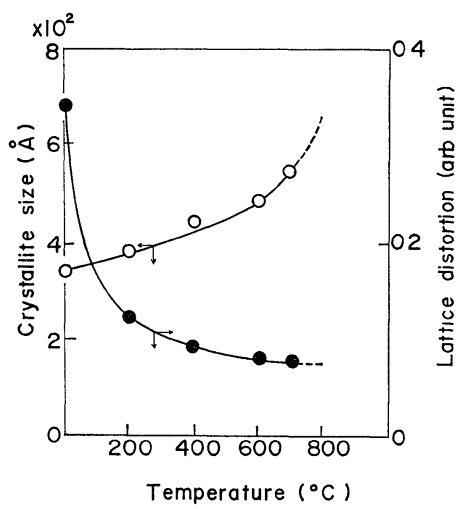

Fig. 3. Change of the crystallite dimension and the lattice distortion of zinc oxide heated for $3 \mathrm{hr}$ after grinding for $200 \mathrm{hr}$.

\section{$3 \cdot 2$ 粉砕試料の示差熱分析}

緒言でも述べたように格子ひずみの除去はひずみエ ネルギの放出を伴い，その際の熱的測定が期待できる. 以上の観点から粉硕試料について粉砕時間の相違によ る示差熱分析の結果を検討した。

Fig. 4 に未粉砕試料の示差熱分析之同条件下での熱 


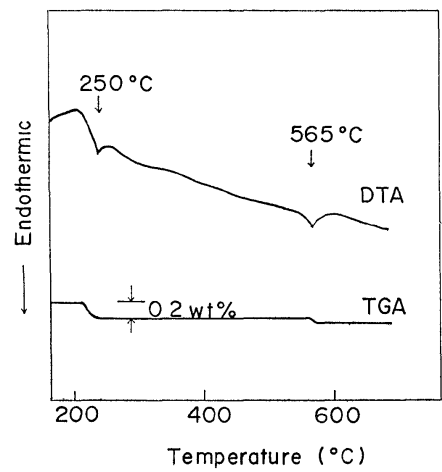

Fig. 4. DTA and TGA traces of original zinc oxide at heating rate of $20^{\circ} \mathrm{C} / \mathrm{min}$.

てんびんによる加熱時の重量変化との関係を示す．

$250^{\circ} \mathrm{C} ， 565^{\circ} \mathrm{C}$ 亿吸熱ピークを示し，同時にそれぞれ の温度で 0.2 特よび0. $04 \%$ の重量減を示す。したがっ てこれらの温度で明らかに吸着物質の脱離現象を生じ ていることを示している。この脱離現象は $80^{\circ} \mathrm{C} ， 6$ 時 間, $0.2 \mathrm{mmHg}$ の減圧下の乾燥試料にる現われ, 安定 な化学吸着物質の脱離であることを示している。一方 粉砕試料では $250^{\circ} \mathrm{C}, 565^{\circ} \mathrm{C}$ の吸熱ピーク以外に $220^{\circ} \mathrm{C}$ 以上飞発熱ピークを生じる。この発熱ピークは200時 間以上の粉砕で顕著であり, 長時間粉碎とともに高温 側に移動し，かつピークの大きさも増大する. その状 態をFig. 5 に示す. しかもこれら発熱ピークに相当す る温度での重量変化はなく, 吸着には無関係なピーク であることを示している.さらにこの発熱ピークの原 因となるるのはきわめて不安定で長時間粉碎試料を $200^{\circ} \mathrm{C} ， 1$ 時間，加熱処理した試料では現われず，ま た室温で長時間（1か月以上）放置した粉砕試料でも 現われない，以上の結果，特よびFig. 2，3 亿示した X線回折による格子ひずみの成長特よび消失の状態と

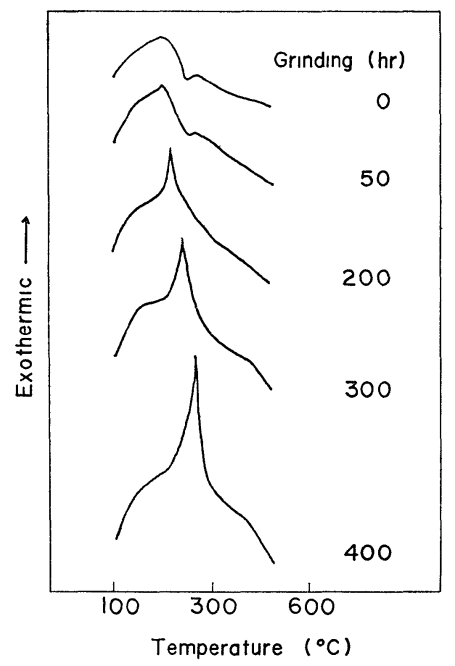

Fig. 5. DTA traces of ground zinc oxide.
を比較して, これらの発熱ピークは格子ひずみ除去の 際の放出エネルギによるものと考兄られる。事実粉碎 試料を長時間室温放置することにより格子ひずみの減 少がX線回折によってる認められ上述の発熱ピークと 同様の挙動を示すことが認められた。

\section{$3 \cdot 3$ 粉砕試料の溶解熱}

酸化亜鉛の酸に対する溶解熱については古くPranschke, 近藤ら, Peppler 5の ${ }^{20}$ の測定がある. しかし酸 化亜鉛の溶解熱を決定する因子としては格子ひずみ， 久陥などの格子不整, 粒度, 表面状態が重要であり, したがって試料の生成履歴, 測定前の試料の処理条件 などの相違が溶解熱の測定涼響を与えるため, 試料 によってその值は必ずしも一致しない，このことは溶 解熱の測定が試料の構造, とくに格子不整を知る上に 有用な手脚りとなりらることを示している。

高橋らは酸化亜鉛の硫酸中への溶解熱を測定して, 400 時間までの粉砕試料では 200 時間の粉砕で溶解熱 が最大值を示すことを認めた。このことは溶解熱の決 定因子として，ひずみエネルギの放出が重要であるこ とを示している.本実験で得られた粉碎後の酸化覀鉛 の塩酸中への溶解熱の変化を Fig. 6 飞示す.

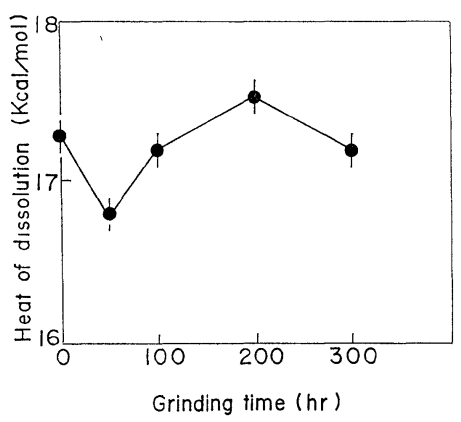

Fig. 6. Heat of dissolution of zinc oxide $(0.15 \mathrm{~g})$ in $2 \mathrm{~N} \mathrm{HCl} 100 \mathrm{ml}$ as a function of the grinding time.

これらの結果は試料および測定条件の相違により, 高橋らの得た硫酸中への溶解熱と比較して, その絶対 值は異なるが粉砕時間による溶解熱の増減傾向は相似 であることを示している.すなわら未粉砕試料に比べ て粉砕後の酸化亜鉛の溶解熱は50時間で減少し，その 後 200 時間まで増大するが, その後の粉砕で再び減少 する. 溶解熱決定への寄与が主として粒度, 格子不整 によるものであり，粒度の減少が溶解熱の減少を伴い， 格子ひずみが溶解熱の増大を伴らことを考慮するなら ば, 最初の50時間までの減少は粉砕による粒度の急減 によるものと考觉られ，この傾向は Fig. 2 の線回折 の結果とも一致する.さらに 200 時間粉砕までの溶解 熱の増大は格子ひずみの増大による効果を示すものと 考光られる.さらに 200 時間以上での溶解熱の減少は 
Fig. 2 で示されるように 300 時間で格子ひずみがほぼ 飽和值に達した後の粒度の減少, それに伴う表面構造 の変化, 吸着物の増大, 長時間粉砕に伴う不純物の影 響などが考えられるであるら．Fig. 5 で示した示差熱 分析の結果から，本実験の条件下では長時間粉砕によ りひずみエネルギの再放出が生じているとは考党が たい.

\section{4 結語}

ボールミルによる粉砕時間の相違によって生じる酸 化互鉛の格子ひずみの状態をX線回折法, 示差熱分析, 塩酸中への溶解熱の測定などによって調べ，それらの 結果を比較検討した。

示差熱分析の結果, $220 \sim 260^{\circ} \mathrm{C}$ の温度範团にひずみ エネルギ放出に伴らと考兄られる発熱ピークを認め, この発熱ピークの粉砕, 加熱による成長および減少の 倾向はX線回折法によって求めた格子ひずみ量の変化 と同一学動を示した。また格子ひずみの減少は $200^{\circ} \mathrm{C}$ の加熱処理で顕著であり, 室温でも粉砕後長時間放置 により，ある程度の減少を示した。

\section{参 考 文 献}

1) 久保輝一郎, 化学々工業, 16, 901 (1963).

2）久保輝一郎, 宮崎高嶺, 工化, 71, 1301 (1968).
3) 神保元二, 工化, 71, 1309 (1968).

4）宇田昭知, 小野武彦, 荻野義定, 工化, 71, 1352 (1968).

5）貞広嘉和, 清水 清, 工化, 71, 1374 (1968).

6) Takahash1, H, and K. Tsutsumi, Bull. Chem. Soc Japan, 40, 7 (1967).

7) Takahashi, H., and K. Tsutsum1, Bull. Chem. Soc. Japan, 40, 542 (1967).

8）貞広嘉和, 清水 清, 材料, 18, 471 (1969).

9）高橋 浩, 堤 和男, セラミックス, 2, 99 (1967).

10）高橋 浩, 堤 和男, 工化, 71, 1345 (1968).

11）高橋 浩, 堤 和男, 工化, 71, 1349 (1968).

12）高橋 浩, 堤 和男, 東大生研報告, 20, No. 1 (1970).

13）貞広嘉和，材料， 21，520 (1972).

14）岩崎弘通, 松田二郎, 第 9 回粉体に関する討論会講演要 旨集, p. 133 (1971).

15）岩崎弘通, 松田二郎, 材料, 21，610 (1972).

16）岩崎弘通, 松田二郎, 昭和 47 年 嚜協年会講演要旨集, p. 114 (1972).

17）岩崎弘通, 松田二郎, 第10回粉体に関する討諭会講演要 旨集, p 124 (1972).

18) Pranschke, A., and H.E. Schwiette, Z.anorg allgem Chem., 223, 225 (1935).

19）近藤禮一, 水渡英二, 物理化学の進歩, 15, 145 (1941).

20) Peppler, R. B., and E.S. Newman, J. Research Nat. Bur. Standards, 46, 121 (1951). 